\section{Svakt om nyresykdom}

El Nahas M, Levin A, red. Chronic kidney disease

A practical guide to understanding and management. 304 s, tab, ill. Oxford: Oxford University Press, 2009. Pris GBP 40 ISBN 978-0-19-954931-3

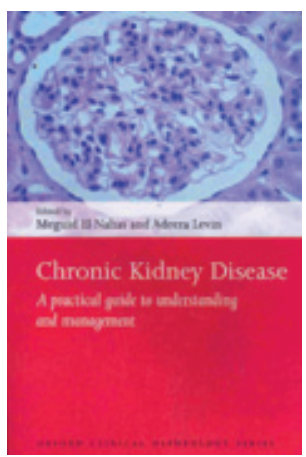

Bevisstheten er økende når det gjelder kronisk nyresykdom, en tilstand som rammer stadig flere, særlig eldre og personer med hjerte- og karsykdom eller diabetes. Denne boken er ment å være praktisk med tanke på å forstå og

behandle kronisk nyresykdom. Målgruppen er allmennpraktikere, indremedisinere og yngre leger i spesialistutdanning. Det er 22 forfattere, hovedsakelig fra USA og Storbritannia, som har skrevet de ti kapitlene. Det starter veldig bra om samhandling mellom primærlege og nyrespesialist med en praktisk tilnærming til bl.a. proteinuri, hematuri, hypertensjon, diabetisk nyresykdom og nedsatt nyrefunksjon, men så sklir det helt ut etter min oppfatning. Man tar seg litt inn igjen i de siste kapitlene der dialysepasienter og transplantasjon blir diskutert i et primærlegeperspektiv.

Redaktørene av denne teksten burde ha hatt strammere tøyler når det gjaldt emneområde, og dermed forhindret betydelig overlapp og repetisjoner. Det virker som om kapitlene ikke er samordnet. Klassifisering og stadieinndeling av kronisk nyresykdom er gjentatt til det kjedsommelige, med bl.a. fire ganger tilnærmet samme tabell og i en figur, i tillegg til tekst ulike steder. Det samme gjelder for terminologi og definisjon av proteinuri/albuminuri, til dels med noen små variasjoner i tabellene. Forfatterne bruker enten konvensjonelle enheter, SI-enheter eller eldre enheter, f.eks. for kreatinin, albumin og kalsium, avhengig av hvilket land de kommer fra. Blodtrykksmål er også angitt litt forskjellig, avhengig av hvem som har skrevet kapitlene. Noen store kliniske forskjeller er det ikke, men det virker skjemmende for helhetsinntrykket. Indekseringen er ikke optimal, ved søk på blodtrykkskontroll oppgis to sidetall, til tross for at dette nevnes langt flere steder. Den mest utfyllende omtalen er ikke angitt.

Tatt i betraktning målgruppen er enkelte kapitler overambisiøse i sin oppramsing av sjeldne infeksjonssykdommer som årsak til kronisk nyresykdom. Praktisk viktig informasjon om medikamenter og nyrefunksjon er bare så vidt nevnt, som i kapitlet om dialyse og nyretransplantasjon, men burde ha fătt langt større plass.
Redaktørene må få ros for at de har tatt inn relativt mye om nyresykdom i utviklingsland og forskjeller i forekomst av kronisk nyresykdommer i ulike land, i etniske grupper og i minoritetsgrupper i vestlige land. Videre er forekomsten av hjerte- og karsykdom blant kronisk nyresyke grundig omtalt. Norske data fra Nord-Trøndelag er behørig sitert, og man har særlig merket seg den betydelig lavere forekomsten av nyresykdom i sluttstadiet i forhold til f.eks. USA. Man tolker det som et resultat av mindre overvekt og tidligere henvisning til nyrespesialister. Men hvor praktisk boken er, kan vel diskuteres.

Min konklusjon er dessverre at boken ikke kan anbefales verken for allmennpraktikere, leger i spesialisering eller andre - til tross for at enkelte kapitler er bra og at den er i tiden ved å diskutere samhandling og inkludere minoritetsproblematikk. Man kan tilegne seg kunnskapen enklere og bedre fra nyere lærebøker og Internett.

\section{Ingrid Os}

Nyremedisinsk avdeling

Oslo universitetssykehus, Ullevål

\section{Nyttig om elektromyografi}

Kamen G, Gabriel DA.

Essentials of electromyography

265 s, ill. Leeds: Human Kinetics, 2010.

Pris GBP 42

ISBN 978-0-7360-6712-6

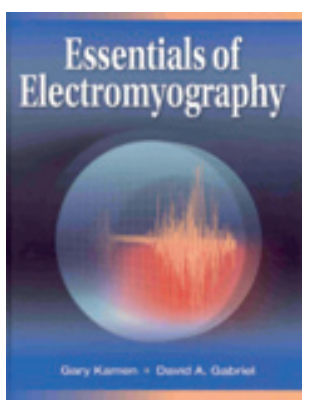

Dette er en introduksjon til faget, skrevet for studenter, forskere og helsepersonell med ulik fagbakgrunn som jobber med elektromyografi (EMG). Teksten retter seg ikke spesielt mot leger som bruker elektro-

myografi i klinisk nevrofysiologi. Diagnostisk nåleelektromyografi er kun summarisk omtalt.

Forfatterne legger vekt på å forklare viktige fysiske prinsipper for hvordan elektriske signaler fra muskelfibre summeres og filtreres i vevet, og hvordan signaler kan registreres og analyseres med forskjellige typer elektroder, utstyr og signalbehandlingsteknikker. Leseren får nyttig informasjon om viktige teoretiske dipolmodeller, men også praktisk informasjon om plasseringen av overflateelektromyografielektroder. Dette er anvendelig kunnskap for alle som bruker elektromyografi i forskning og klinisk arbeid.

En del informasjon om muskelbiologi og elektromyografi som ellers kan være vanskelig tilgjengelig, er samlet her. Det er referanser til mange lærebøker og originalog oversiktsartikler. En nyttig ordliste er også inkludert. Teksten er lett å lese og ledsaget av enkle, ofte godt forklarende strektegninger og figurer. Avsnittene avsluttes med en repetisjon av viktige hovedpunkter, noe som vil hjelpe innlæringen.

Forenklingen synes å gå for langt noen steder i anatomi-fysiologi-kapittelet. Omtalen av relasjonen mellom ionekonsentrasjoner og aksjonspotensial er delvis misvisende, og teksten skiller feilaktig ikke mellom miniatyr-endeplatepotensialer (MEPP) og endeplate-spikes. Motor unitfigurene inneholder enkelte småfeil (1.10), og en figur (1.6) kan mistolkes i retning av at nabofibre oftest tilhører samme motor unit, noe som ikke er tilfelle (dette er korrekt angitt i teksten). Minimal fyringsfrekvens for motor unit er nok noe lavere (ca. $2 \mathrm{~Hz}$ ) enn det som angis i teksten $(5-10 \mathrm{~Hz})$. Det er derfor helt nødvendig at studenter supplerer med å lese en god lærebok i fysiologi.

Teksten inneholder matematiske formler, men den grunnleggende forståelsen av stoffet er ikke avhengig av spesiell matematisk kunnskap. Boken har en nyttig og godt skrevet gjennomgang av filtrering, behandling av støy, digitalisering, korrelasjonsanalyse og frekvensanalyse av EMG-signalet. En del teoretisk stoff er plassert i korte appendiks.

Sammenhengen mellom EMG-signal, muskelkraft og trettbarhet (fatigue) omtales $i$ et eget kapittel. Andre applikasjoner som omtales, er ganganalyse og fremkalte EMG-responser (M-bølger, H-reflekser og F-bølger). Bruk av elektromyografi til å bestemme nerveledningshastighet og sentral ledningstid etter transkraniell magnetstimulering er kun summarisk nevnt.

Boken kan ikke på noen måte erstatte en standard lærebok i elektromyografi og klinisk nevrofysiologi for leger under spesialisering. Den anbefales likevel som supplerende litteratur for alle spesialister i klinisk nevrofysiologi. Andre leger, studenter, annet helsepersonell og forskere som benytter elektromyografi i bevegelsesanalyser, vil ha spesiell nytte av den som en introduksjon til faget.

\section{Trond Sand}

Institutt for nevromedisin

Norges teknisk-naturvitenskapelige universitet 